\title{
Uplifting the socio-economic empowerment of women through handicraft industry
}

\section{Upaya peningkatan pemberdayaan sosial ekonomi perempuan melalui industri kerajinan}

\author{
Shahina Bano', Neelam Farid ${ }^{1}$, Asia Ashfaq ${ }^{2}$, \& Siti Mas'udah ${ }^{3 *}$ \\ ${ }^{1}$ Department of Sociology, International Islamic University Islamabad, Pakistan \\ ${ }^{2}$ Department of Humanities and Social Sciences, Bahria University Islamabad, Pakistan \\ ${ }^{3}$ Department of Sociology, Faculty of Social and Political Sciences, Universitas Airlangga \\ Address: ${ }^{1} \mathrm{H} 10$, Islamabad, Pakistan 44000 \\ ${ }^{2}$ Shangrilla Rd, E-8/1 E 8/1 E-8, Islamabad, Islamabad Capital Territory, Pakistan \\ ${ }^{3}$ Jalan Dharmawangsa Dalam, Airlangga, Surabaya, East Java, Indonesia 60286 \\ E-mail: siti.masudah@fisip.unair.ac.id
}

Article History: Received 09 July 2021; Accepted 17 November 2021; Published Online 29 November 2021

\begin{abstract}
Empowerment is seen as being capable of making choices about job, marriage, mobility, entertainment, and the number of children. The present study focused on the role of handicraft businesswomen, their experiences, and the role of handicraft business as a tool of empowerment for women in Gilgit, Pakistan. The study was limited to the experiences of women producing handicrafts and viewed as socio-economic empowerment for those who are producing handicrafts. This study employed a qualitative research design. The thematic analysis of interviews of the craftswomen showed that they were empowering themselves economically and socially through handicraft business. The research findings reinforced the objectives of the study that the craftswomen perceive empowerment as economic independence and the income generated through handicrafts strengthens their economic as well as social position in society. This study concludes that their economic and social position becomes stronger after starting to earn income. These women also felt like the source of change in terms of motivation, inspiration, and encouragement for the other women in the society. They viewed and regarded the skill of handicrafts as the source of income and financial support for their families.
\end{abstract}

Keywords: economic support; employment opportunities; skill development; women's empowerment

\begin{abstract}
Abstrak
Pemberdayaan dipandang sebagai kemampuan untuk membuat pilihan tentang pekerjaan, pernikahan, mobilitas, hiburan, dan jumlah anak. Kajian kali ini berfokus pada peran perempuan pelaku usaha kerajinan tangan, pengalaman mereka, dan peran usaha kerajinan tangan sebagai alat pemberdayaan perempuan di Gilgit, Pakistan. Kajian ini dibatasi pada pengalaman perempuan yang memproduksi kerajinan tangan dan dipandang sebagai pemberdayaan sosial ekonomi dari mereka yang memproduksi kerajinan tangan. Penelitian ini menggunakan metode kualitatif. Analisis tematik wawancara para perajin menunjukkan bahwa mereka memberdayakan diri secara ekonomi dan sosial melalui usaha kerajinan tangan. Temuan penelitian memperkuat tujuan studi bahwa perempuan perajin memandang pemberdayaan sebagai kemandirian ekonomi dan pendapatan yang dihasilkan melalui kerajinan memperkuat posisi ekonomi dan sosial mereka di masyarakat. Studi ini menyimpulkan bahwa posisi ekonomi dan sosial mereka menjadi kuat setelah mulai mendapatkan penghasilan. Para perempuan ini juga merasa menjadi sumber perubahan dalam hal motivasi, inspirasi, dan dorongan bagi perempuan lain di masyarakat. Mereka memandang dan menganggap keterampilan membuat kerajinan tangan sebagai sumber pendapatan dan dukungan finansial bagi keluarga mereka.
\end{abstract}

Kata kunci: dukungan ekonomi; kesempatan kerja; pengembangan keterampilan; pemberdayaan perempuan

\section{Introduction}

Empowerment is seen as being capable of making choices about job, marriage, mobility, entertainment, and the number of children. In this way, empowerment can be defined as growth in the ability of people 
to make deliberate life choices in circumstances where this capacity was previously invalidated (Kabeer 2011). Over the past few years, there was a considerable increase in research about empowerment, especially in the areas of developmental work and political science (Mosedale 2005). Female home industry workers show multi 'burden' roles, flexible working hours, but no special education related to working. The formulation of a model for empowering poor women and a more optimal gender mainstreaming strategy are needed for the development of a small home-based industry that is managed and employs poor women (Hashemi et al. 1996, Susanti \& Mas'udah 2017).

Studies on empowerment in Pakistan show that the success of women's empowerment depends on the content of education, economy, women's participation, poverty, and economic opportunities (Bushra \& Wajiha 2015). Empowerment of women by providing microfinance services has been successfully implemented in Pakistan by being able to improve family welfare. Microeconomic plans are provided to women through interest-free loans. This increases their well-being because Pakistani women generally spend their money on meeting family needs (Rehman et al. 2015). Meanwhile, women's empowerment in India is carried out by forming self-help groups to pave the way for women's independence. Self-help groups are able to create jobs, increase income, strengthen purchasing power, reduce costs, and increase business convenience (Kabeer 1999, Datta \& Gailey 2012, Paramanandam \& Packirisamy 2015, Datta 2015, Brody et al. 2016).

Women's empowerment is defined in two ways, including empowerment as a goal and empowerment as a process. Empowerment is not merely a product; rather it is an ongoing process that could not be considered as a final goal. It is an ongoing process that enables the powerless to have control over their social and economic circumstances in their lives.

The present study focused on the role of handicraft businesswomen, their experiences, and the role of handicraft business as a tool of empowerment for women in Gilgit, Pakistan. The handicraft business is defined as special expertise and skill transferred from elders to their future generations. Handicrafts are specialized skills that provide a source of livelihood for craftsmen. The terms artisans and craftsperson are mostly used interchangeably, referring to "household industries", "cottage industries", "handicrafts", or "traditional industries". In addition, 'crafts' are defined as items having clear aesthetic worth or those with exhibited trade achievement. Others incorporate any activities that include manual work. Many people knowing traditional techniques and traditional skills are earning a livelihood by producing handcrafted goods (Liebl \& Roy 2003).

Female entrepreneurs not only contribute to employment creation and economic growth through their increased participation but also add the diversity and quality of entrepreneurship in the economic process (Verheul et al. 2006, De Jong 2013, OECD 2016). Usually, it is hard for women to work and create some home-based products. In Pakistan, the status of women is not the same as that of men given the interconnection of sexual orientation with different types of ostracism in society. Similarly, religious sayings or practices, social standards, and practices identified with the status of women and job variations are also sometimes conflicting in society. Moreover, social mores, feudal systems, and capitalists can limit the activities of female entrepreneurs all through their working lives (Roomi \& Parrott 2008).

In Pakistani culture, it is common to teach some craftworks to young girls regardless of whether their families are educated or uneducated. Uneducated families, however, put more emphasis on it. Sewing, embroidery, knitting, crochet, rally-quilts, and handmade scarf (chuniri) are among the common crafts which are taught to young girls while the most common and popular craft is embroidery. At large, women in rural areas know the craft of embroidery as learning embroidery starts from a very young age. They do embroidery on bedsheets, veils, cushion covers, table covers, shirts, pillow covers, scarves, and mantel covers for their dowry and household use. Women make bed sheets, cushion covers, shawls, rugs, bags, scenery decorations, wall hangers, shoes, sofa backs, table covers, clothes, and jewelry; they make the goods on orders for dowry and household use (Mohyuddin et al. 2012). 
In Gilgit, Pakistan, the economy of the household is not dominated by men. Rather, women from a very early age start taking part in the household economy by making handicrafts, keeping livestock, and poultry. These women do a lot of embroidery and cross-stitch (char sutta) which is acclaimed both locally and globally. These handicrafts are sold to local people as well as tourists who come especially in summers and exported to other countries. However, these handicrafts are sold at different prices to local people and tourists. As a result summer season bring ample profit to these craftswomen with the arrival of tourists.

The advancement of women's status and their empowerment are basic elements for realizing the total potential of financial, political, and social improvement and guaranteeing economic development. The process of empowerment magnifies women's accessibility to economic resources and opportunities; raises women's self-confidence, and raises women's awareness about the indications and causes of abuse (Khan 2006). In this manner, empowerment enables women to meet their practical necessities.

Jo Rowlands (1995) in her theory of empowerment talks about three dimensions of empowerment including personal, relative, and collective empowerment. Women are experiencing empowerment at these three levels by producing and selling out handicrafts in Gilgit District. According to Rowland's point of view, the idea of empowerment is more used as an instrument for understanding what is needed to change the condition of marginalized and poor people. In this way, there is a greater agreement that empowerment is a process; it involves a certain degree of human development, but that this is not enough; and it includes the act of transitioning from insight to activity (Rowlands 1995). Rowlands is considerably focused on the empowerment of women and proposes that the method includes changes in women's individual life, connections, and collectivity. In her point of view, people are empowered when they can maximize the opportunities accessible to them without obstacles.

It is generally recognized that without women's advancement, no improvement can be significant. Moreover, the commitment of women in family income is assumed to clear their way for decisionmaking in family affairs (Kabir \& Huo 2011). Globally, the rate of unemployed women is higher than men. Likewise, women also make up the highest share of the lower-paid, unorganized casual segment of most economies. So, women's vulnerability to poverty can be considerably reduced by providing finance for activities that help in income generation and access to microfinance institutions. Therefore, reduction in women's vulnerability can be considered as directly proportional to empowerment, if financial security allows them to experience self-confidence in the house and community affairs.

Handcrafted items are characterized as items made frequently with the utilization of basic tools and are aesthetic or customary in nature. These goods are simply made by the aptitude of the hand possessed by the maker and it involves centuries of evolutionary tradition. Even though handicrafts were done by more old and experienced women in the past, the participation of the more youthful age has been noticed. Handicrafts in the rural and the urban regions serve as a technique for survival among the low-paid social class and on such grounds ought to be a fully equipped financial sector. Handicrafts also have cultural and social importance to many as they are mostly produced using indigenous plants. Subsequently, indigenous information assumes a pivotal role in the aptitudes required for the creation and protection of these items as most of them depend on indigenous abilities and are produced using locally-accessible resources.

Stereotypically, women are considered less powerful because they are primarily dependent on the male members of society. Similarly, not highly educated women were considered feeble with little basic leadership ability, and unconscious of their privileges and opportunities. Prior to marriage, decisions were made by their parents, while after marriage they were made by her significant other and in-laws as men are essential chiefs in the family. A solid sense of self and a forceful personality towards his wife and family was seen as acknowledged by society. A man may vent his annoyance on his wife without fearing the responses from other relatives (Ali et al. 2011). Different Local Supportive Organizations 
(LSOs) are also playing a vital role by providing capacity-building projects to these local craftswomen (Ali et al. 2016). It is also important to study whether women who are taking part in the traditional occupation of handicraft production are experiencing empowerment on the same level as those working in different other fields outside their houses like farming (ILO 2012). In the field of economy, the association of women at a massive scale is associated with an advanced way of living. Globally, women are seen making a notable involvement in economic and business advancement. When they are socially and economically equipped, they become a powerful force for change (Faiz-ur-Rehman et al. 2017).

Traditionally, in Pakistani rural societies, women are not encouraged to work outside their homes. Cottage and small-scale industries like embroidery, carpet weaving, and handicrafts can be established and women can be gainfully employed. The current study specifically focuses on those women who are making handicrafts at home and becoming a source of earner by staying within the boundaries of home. The families of these women depend on the income which they earned by making handicrafts. The makings of handicrafts are empowering women economically and socially in Gilgit Baltistan because there is a great demand for handicrafts in national as well as international markets. In this regard, the present study aimed to explore the role of handicraft making in the empowerment of women in the Gilgit District. Furthermore, the current study makes an important contribution to the body of knowledge on women's empowerment through handicrafts.

The conception of empowerment of women has remained a matter of much intellectual discourse over the last few years. Empowerment is defined as the procedure with the help of which women take ownership and control of their lives through the enlargement of their options. Therefore, it is the method of obtaining the capacity to create key life choices in a setting where this capacity has already been denied. Furthermore, empowerment may be a procedure whereby women ended up being able to organize themselves to extend self-reliance, state their autonomous right to form choices, and control assets (Bhandari 2014). Empowerment happens when women can raise their negotiating power through a strategy of grassroots activism and arrangement. In developing nations, there are limited resources and there is a need for government policy in empowering women. Likewise, women who are dynamic in craftsmanship businesses pick up new energy and a sense of empowerment that they get through active participation in leadership and decision-making. Women who accept authority parts in such innate crafted works businesses demonstrate to be more mindful, compassionate, and able to meet the requirements of their families and communities (Datta 2003).

The advancement of women's status and their empowerment are basic elements for realizing the total potential of financial, political, and social improvement and guaranteeing economic development. Therefore, I argue that the process of empowerment magnifies women's accessibility to economic resources and opportunities; raises women's self-confidence, and raises women's awareness about the indications and causes of abuse (Khan 2006). Women empowerment is not possible without the active participation of women in the economy and therefore, women must have access to entrepreneurship and business. The handicraft's work is the main area that is legitimately connected with the abilities of women so there is a critical need to improve it. About 65 percent of women win their job from craftsmanship work. Cottage industries gain a vital position, particularly in the provincial set-up as customarily women are not urged to work outside their homes in these areas. In this manner, a noteworthy number of women in Pakistan are occupied with tailoring and handicraft activities. For instance, up to 30 to 40 percent of women in NWFP are engaged in handicrafts and cottage industries. The product range of handicrafts includes ceramics, ajrak, farassi rugs, khes, jandi, articles made of date leaves, caps, bangles, kasha, crochet work, appliqué, embroideries, and wood carving (Makhdoom et al. 2016).

Women's income generation prompts a multiplier impact in their local communities. Production of crafts is a potential opportunity for income generation for women who do not have enough mobility frequently because of their absence of land rights and numerous family unit obligations. Craft production is outstanding for its availability to women; it does not expect access to land or proficiency and is not physically requesting work. It is accessible to the handicapped, enables women to work in their homes, 
offers adaptability in hours, and regularly fuses customary aptitudes of women today. For women in lesser-developed communities, craftsmanship generation regularly leads to salary generation and progressed quality in all spheres of their life (Shealy 2011).

The foremost self-evident advantage of craftsmanship generation is the generation of income. However, craftsmanship generation yields more. Production of crafts uplifts women's feelings of self-esteem and freedom. It permits open doors for innovative self-sufficiency and articulation and uplifts the status and roles of women inside their networks. Besides, as women are more likely to contribute their cash to their children than men, the production of crafts permits women to upgrade positive social change in their communities (Shealy 2011). The majority of women in rural areas have mastered the craft of embroidery. They begin learning this craftsmanship from a young age. They do embroidery on bed sheets, shirts, cushion covers, veils, pillow covers, table covers, and mantel covers for household use. After the craft of embroidery, crochet work is the foremost prevalent workmanship among the ladies within the town.

Handcrafted items are for the most part characterized as items made frequently with the utilization of basic tools and are aesthetic or customary in nature. These goods are simply made by the aptitude of the hand possessed by the maker and it involves centuries of evolutionary tradition. India is one of the major providers of handicrafts in the world and the industry of handicrafts are located in rural as well as in urban areas (Dar \& Parrey 2013). The handicrafts sector plays a noteworthy and significant job in the nation's economy. In rural and urban areas, this sector provides employment opportunities to many craft persons and produces generous foreign exchange for the nation while preserving and promoting its cultural heritage. Crafted works have incredible potential as they hold the key for supporting not just the millions of working craftsmen spread all over the country, but also the undeniably enormous number of new contestants in the crafts industry. Currently, handicrafts contribute greatly to the generation of employment and exports. Besides, the high business potential in this area is financially significant, involving the purpose of low capital venture, a high proportion of significant worth expansion, and potential for trade and outside trade income (Dar \& Parrey 2013).

In less developed communities, the production of handicrafts often leads to the generation of income for the women which subsequently helps them to upgrade their quality of life. However, there is much debate on the role of handicrafts within economic development; some contend that utilizing craftsmanship for development starts lost custom as craftsmen adjust their items for outside business sectors. However, to support income, craftsmen must make drafts advised by the demand of the market which will not only polish their skills but also provide them a maximum advantage at the individual as well as the collective level (Shealy 2011).

Because of the worldwide appeal of craftswomen in the previous few decades, plenteous development in numerous women who held businesses has been seen and their input to financial advancement, the creation of employment opportunities, and development in numerous economies have built up. It eventually provided them with multiple benefits to uplift their economic conditions. Entrepreneurship is one of the significant components of the economic growth of a country. For women, there could be many influencing factors such as education, family business, friend's inspiration, and an intention to make oneself financially stable in the future by taking on entrepreneurship as a career (Jabeen et al. 2018).

Jo Rowlands, a gender researcher, in her article "Development in Practice" has written on empowerment in the context of gender and development. She analyzes that the meaning of empowerment could not be defined precisely but generally, it is defined as a process rather than a finished product (Rowlands 1997). According to Rowland's point of view, the idea of empowerment is more used as an instrument for understanding what is needed to change the condition of marginalized and poor people. In this way, there is a greater agreement that empowerment is a process as it involves a certain degree of human development, but that this is not enough; and that it includes the act of transitioning from insight to activity (Rowlands 1995). Rowlands is considerably focused on the empowerment of women and proposes the method includes changes in women's individual life, connections, and collectivity. In her 
point of view, people are empowered when they can maximize the opportunities accessible to them without obstacles. She demonstrates that there are three dimensions in which empowerment executes, including the personal, relational, and collective dimensions, with a focus on the different contexts in which empowerment is demonstrated and experienced. Each dimension has certain core principles that contribute to the transformation of individuals, represented as the "key" that opens" locks" on the empowerment door (Rowlands 1997).

We have adopted the theoretical stance of Jo Rowlands 'dimensions of empowerment' where she views empowerment as a dynamic process. This process starts with the personal dimension of empowerment. At this dimension, empowerment is about developing a sense of self and individual confidence or capacity. By involving in the production of handicrafts, women recognize their sense of the individual that they can identify themselves by earning through these handicrafts. This not only boosts her confidence and self-esteem but also recognition of her capacity as the income generator of the family. At the relational dimension, empowerment is about establishing relationships with the partner and other members of the family. By being an earner of the family through selling out the handicrafts, women can modify their family relationships. This gives them a sense of empowerment as they can make decisions about their children's education and socialization. They can negotiate her decisions with her partner as well as the family members. At the collective dimension, women can recognize their worth at the institutional level. For example, a group of craftswomen can influence their surroundings in a village by cooperating. By observing such groups, other women of the society might be encouraged to become income generators, leading them to empower themselves.

\section{Research Method}

The research opted for the qualitative research design and data was gathered through informants and participants. In this research, women's empowerment is the main variable that is specified with economic and social empowerment. The qualitative research design was used for a deep understanding of the role of handicrafts in women's empowerment.

This research design gives a better understanding of the current study as it is a unique research design to study the empowerment of businesswomen of handicraft in detail. In the current study, the informants were the craftswomen who were making handicrafts while staying at their homes. The informants of the current research were nine craftswomen from the Gilgit District, Pakistan. The study has some specific objectives including observing the role of the handicraft industry in women's empowerment, examining the role of handicraft industry in women's economic empowerment, exploring the role of handicraft making in women's social empowerment, and finding the career development prospects for the craftswomen.

The researcher has considered the ethical aspect of the informants in this current study. The researcher has highly considered the confidentiality of the informants and strictly followed the ethical consideration of this research during and after the data collection. Furthermore, the researcher considered the privacy of the informants as well by giving them pseudo names in the research report. The interviews were taken after taking the consent of the informants (craftswomen). The audio recording and some pictures of handicrafts were captured after obtaining consent from the informants. Data were analyzed, interpreted, and discussed with the previous studies relevant to the topic of this study. The conclusion was drawn to highlight the contribution of knowledge of this study.

\section{Results and Discussion}

\section{Perception of empowerment}

The present theme aims to discuss the meaning and perception of empowerment for the craftswomen, particularly how they perceive and understand this term empowerment. Empowerment has been 
defined as "the procedure of growing ability of individuals or groups to make choices and transform those choices into preferred actions and outcomes. The word 'empowerment' is defined by different sociological theorists as the individual's ability and capability to make choices, take decisions about their life freely, and free mobility without any constraints. Mostly, the informants regarded that to be empowered means to be self-sufficient that one is not dependent on others to fulfill his/her necessities of life. For the majority of informants, empowerment is the individual capability of taking decisions about their personal life. One of the informants regarded empowerment as:

"For me, empowerment means to be independent and this is important for a woman to be independent or empowered as it gives women a chance or an opportunity or a benefit to help or support themselves, their spouses, and children financially." (GHU).

The same thoughts were expressed by another informant:

"For me, empowerment is to be self-sufficient in terms of personal economic needs. A woman shouldn't be dependent on her husband, brother, father, or any male member of the family for living her life". (SUL).

The three of the informants explained that the term empowerment means having and owning the decisions of their life. Scholars see that empowerment of the individual means that they must own the power of decision-making (Kim et al. 2007). This means that they have the power to control the domain of decision-making about their lives and other aspects of their lives including decisions related to inside or outside of the house. For the majority of informants, empowerment is the individual capability of taking decisions about their personal life. Rowland viewed (1997) empowerment in terms of having the economic resources. An individual owning the resources automatically gives them the power of decision-making about their life. An individual perceives and experiences empowerment when he or she is empowered economically. The economically-empowered individual takes the decisions freely without any external and internal constraints of the society. One of the informants who expressed her thoughts on empowerment said "For me, empowerment means to be independent in terms of making choices about personal life, family, and children." (SUG). Another informant also explained empowerment as follows. "Empowerment is self-reliance as it gives individuals the power and courage to stand on their own feet." (PAR).

The statements given above regarding the perception of informants on empowerment reveal that all of the informants are well aware of economic empowerment. The majority of the informants perceive empowerment as independence in all spheres of their personal life. This independence is not only limited to economic resources but also independence in decisions regarding their personal life. Generally, economically-empowered women not only improve household resources but also play a positive role in their wellbeing. Their wellbeing ranges from their independent day-to-day activities, their health care, their emotional and psychological well-being, and all this is only possible when they are economically empowered and self-sufficient. Economically, dependent women cannot take economic decisions that marginalize their capacity to work for their wellbeing.

\section{Handicrafts and economic empowerment}

Women's economic empowerment can be defined as a process in which women's lives are shifted from a condition where they have less and limited power to experiencing more and advanced power through the control over assets and resources (Hunt \& Samman 2016). This theme explains the economic empowerment of the informants due to their economic independence earned through handicrafts. Most of the informants mentioned that making handicrafts empowered them economically at home and outside. The word 'empowerment' is originated from "power" and any entity having economic resources has that "power". Mostly in Pakistani society, women are viewed as powerless because they lack economic resources. Man is considered the epitome of power because he is the one who controls the economic resources. Therefore, he has the right to regulate the lives of the people in his life. One of the informants 
viewed economic empowerment as follows."Empowerment is to be self-sufficient economically, not depending on the male member of the family such as husband, father, brother and son" (IFF).

Women's economic empowerment is directly linked with their access to resources and their control over these resources (Hunt \& Samman 2016). The control and usage of these resources by women enables them to control the other areas of their lives. According to three informants, economic empowerment means a state when individuals possess independent economic resources, and possession of this economic resource enables them to fulfill their own needs without any dependency. One of the informants gave her argument in this regard:

\begin{abstract}
"Empowerment for a woman means to stand on her own feet and this is the economic empowerment. In our society (Gilgit), a woman is empowered when she is not dependent on her male family member. For years, a male member bears your expenses. He has other responsibilities too; instead of depending on him, I earn and spend money on myself and on children too. I am not dependent on him anymore and I feel proud of having this feeling (smiles)." (HAM).
\end{abstract}

Most informants shared their thoughts that when they were not involved in this skill of making handicrafts and having no money in their hands, no one from their family valued them in any matter of their domestic area. After earning some money, now their family members (in-laws) consider their value. The two of the informants expressed their opinions that economic empowerment gives them the power and autonomy to make their decisions in terms of spending money on household expenses. The four informants mentioned that a woman only experiences empowerment when she is economically empowered. A woman becomes economically empowered when she earns by herself. In the Gilgit region, a woman earns through two main ways, including by making handicrafts (Figure 1) and by agriculture. One of the informants said:

"In our area, mostly women earn through keeping livestock and by making handicrafts. So for me, these are some fields through which women can earn and support themselves and their families as well. But there is another way to earn money, which is by setting handicraft business in a marketplace. For me, this idea is not good because people in our area do not recognize it as respectful for a woman to set business or open a shop in the market. Making and selling handicrafts while sitting in your own home is more convenient." (REH).
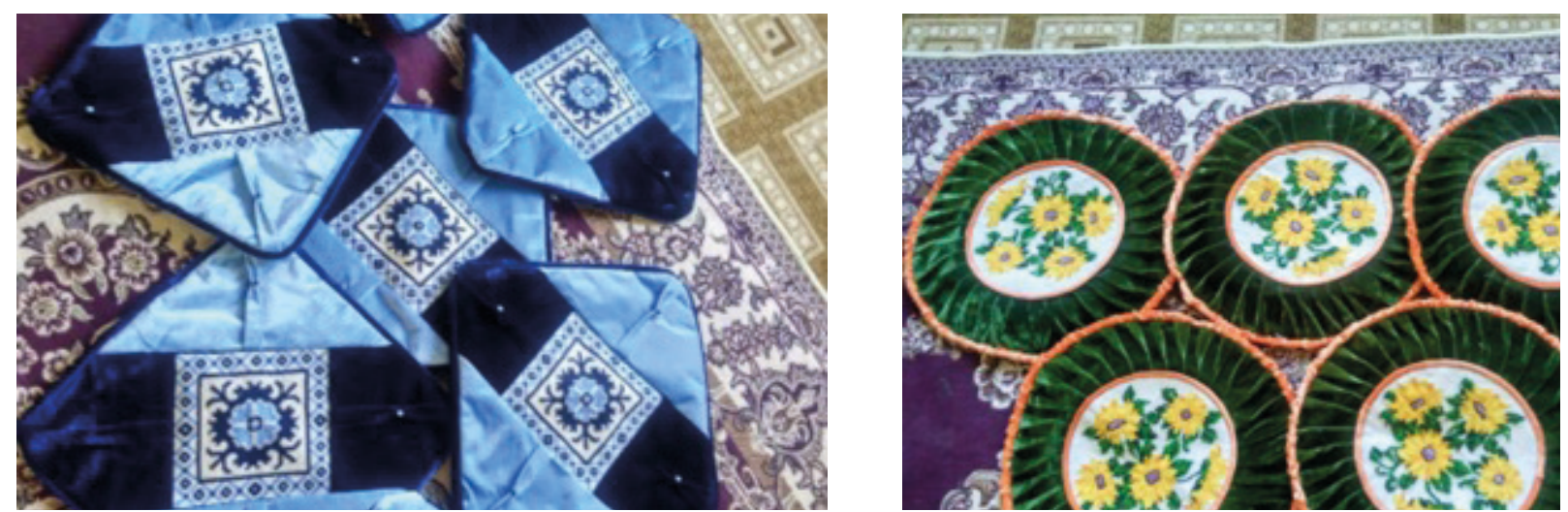

Figure 1.

Some handicrafts made by women in Gilgit, Pakistan Source: Primary data

One of the informants explained that economic empowerment is a blessing. According to her in our society, women's economic empowerment is a blessing from God. She said that only a hard-working woman can experience this blessing and having such a source through which one can earn is another blessing. She explained: 


\begin{abstract}
"Handicrafts are playing an important role in women's empowerment. You can see that without making handicrafts, I cannot accomplish anything else. I cannot sit idle without doing work. Through these handicrafts, I earn and spend my earnings on my welfare and the welfare of my children and family. As I am not educated and due to this I do not have any other source through which I may earn. Handicraft is providing a platform for women like me to earn on their own and empower themselves by improving their conditions." (HAS).
\end{abstract}

It is assumed that owning the income is linked with owning power in the household. The one who has the resources and income then he/she can control the household matters. The different Non-Governmental Organizations and governmental programs are workings to facilitate the women to own the resources and thus own power and further to be economically empowered. The NGOs are providing incomegenerating programs and do such ventures which economically empower women through income (Bhandari 2014).

Other than embellishing their shirts and veils with crochet work, women also make fashionable bed covers, beautiful crochet table covers, sofa backs in beautiful designs, and dressing table covers. Most commonly two types of threads are used in the crochet work i.e. woolen and silken threads. The art of knitting is yet another very famous art among women. Women are so expert and skillful that they only take a week to knit one full sleeve sweater and only three to four days to knit a half sleeves sweater with the best quality (Mohyuddin et al. 2012). The conventional hand embroidery work of Baluchistan is seen on bed sheets and pillow covers, dresses, and shalwar of women and children, caps, etc. Women who are occupied with needlework sell their items inside the network or somewhat carry their completed work to nearby retailers. Usually, there are no opportunities for them to sell outside of their local area and get a maximum advantage (Siddiq \& Kakar 2017).

Changing domestic preferences and rapid globalization have created novel problems and hurdles. The artisans need to get used to formal credit institutions and institutions of long-distance trade as they increasingly manage local and world tourism, new types of entrepreneurs or customs, and government regulations (Liebl \& Roy 2003). The women from the lower and lower-middle-class sell their knitted handicrafts. They accept orders not only from the village but also the mediator and produce as per the demand of the customer. The most profitable activity is still knitting since such orders proceed to pour in all through the winter season. Sewing quilts/mattresses is another source of income for women, especially within the winter season as they are still in utility. This to some extend enables women to gain cash on their own, which makes them feel independent and sufficient. They can spend this cash wherever they want (Mohyuddin et al. 2012).

Earning income enable women to increase their bargaining power in the household and share responsibilities of the household (Saud et al. 2021). This theme aims to discuss and analyze how earning through handicrafts makes the informants a source of economic support to their families. The process of income-earning enhances women's economic autonomy. As a result, they are regarded as influential resources of empowerment. Most informants view that the money they earn from the handicrafts is used and spent on the household's items and their children's education, health, and other daily expenses. Women earn a big amount of income in poor and uneducated communities through crafts industries. They hold the ability to change their economic and social position; they also support and improve the standard of living of their families through this income. Women play the role of the backbone of society. If women are empowere economically and financially, they can prove themselves as the change-makers by providing education facilities to their children, improving the living standard of the family members, and saving for the future of their families (Negi et al. 2016).

\title{
Authority in decision-making
}

The important and significant factors of empowerment are women's increased status and decisionmaking power within the household (Hashemi \& Schular 1993). In this theme, the power of decisionmaking is discussed that how much they're earning from the handicrafts gives them the autonomy 
to make decisions about their lives, family, and the decision to spend the earned money from the handicrafts. Most of the informants view that making handicrafts and earning the income from this skill bestowed them the power of decision making. Additionally, the process of empowerment is one's ability to make choices. This means that making choices is related to making and taking decisions. They viewed empowerment as the relation of their access to have resources, creating agency, and then the achievements. The achievements are the outcomes of the process of empowerment. The women's ability to make decisions is the achievement of the empowerment which she experiences after gaining an economic position.

Females who are engaged in income-generating ventures can change society. These women have the ability and potential to shift the thinking pattern of the people in any specific society. They further can shift the behavior and perception patterns for a positive change in society (Bornstein 2004). This theme presents a discussion on how craftswomen are becoming the source of change in a rural society. The informants stated that they are the change-makers in their society. An informant in this regard shared that first there were few craftswomen in their area. However, due to the higher rate of demands from the local and national markets, new craftswomen also emerged. Small business or female entrepreneurs with access to economic success can offer a new way of thinking to all sectors of society. This new way of thinking leads to a positive and fruitful change for all, especially for the other women of society (Nicholls 2006).

Women's capability to control or make decisions that affect their lives and their futures is measured to be one of the major mechanisms of empowerment. One of the main important signs of women's empowerment is the ability to make decisions within the household. Women's participation in household associations can be established as an indicator of empowerment in numerous studies. Empowerment in this perspective refers to women's ability to identify and characterize their own life choices, make decisions about life choices, and follow their own goals. This is recognized by the fact that they can do a job and be paid. Consequently, they are being given a little acknowledgment and responsibility in the domestic decision-making development (Bhandari 2014). For encouraging and enhancing the skills of craftswomen, training workshops are very significant. The craftswomen would be able to manufacture and market handmade products that could compete successfully in the face of the modern global market. Such training about handicrafts having a goal to change the status of the women in society will generate more income for them. It also aims to provide how they have access to the resources to make handicrafts. These training activities and programs are for marginalized women to make them learn the skill of handicrafts and enable them to consider their sense of worth in society (Richard 2007).

As mentioned earlier, the nature of a male-dominated society shows that most decisions are taken by the male member of the family, and if married women live in a joint family then there are fewer chances of making decisions. As the two informants were living in a joint family system mentioned, it was quite difficult for them to obey the decisions which were taken by the in-laws. One of them said:

"I am living in a joint family system. We have fifteen family members. So, our father in law takes the decisions and we all have to accept and obey the decisions either with happiness or with sadness." (MUK).

It was very interesting to see that the informants who were living in the nuclear family system enjoyed the decision-making autonomy. The informants mentioned that they make decisions about household matters, children's education, and family mutually. They take decisions with mutual understanding and mutual consent. They take decisions mutually about their family matters. One of the informants pointed out that her husband gives her a great value in terms of taking any important decision, as she explained as follows:

"Yes, mostly I make decisions about household matters and family. This is because my husband gives worth and value to my decisions by respecting them. This may be because I am supporting him equally in financial matters. For example, last month I wanted my son to move to a new 
school, so I changed it and my husband accepted this decision as he has trust in my decisions. Mostly I and my husband mutually take decisions". (SAM).

The two of the informants stated that earlier when they were not earning, their spouses did not consider their role in decision-making about their family matters. Once they started earning, their husband's attitude has changed. Now they ask before taking any important and big decision about family matters. One of the informants stated the same views as follows:

"Now he (her husband) takes my thoughts about any family matters before taking a serious decision. He respects my thoughts and values my decision. His attitude has changed since I started earning through handicrafts". (SHEH).

A thoughtful change in the decision-making process that some women in their families can make is their active participation in economic activities and income-generating processes. In most rural areas, male members such as fathers, brothers, husbands, and sons have the power to make decisions for the women. These men decide to which level a woman gets an education, go for work, and go outside of the house. The father and brothers make decisions before marriage. However, after marriage, they are under the authority of their husbands, who rule and control their lives. This is maybe the lower and underestimated position of a woman in rural areas. The economical participation in any activity is linked with the power to take decisions on an individual own (Paterson 2008).

The overall discussion analyzed that women are economically empowered after selling out the handicrafts they made at home. These handicrafts helped them and made them be earners and productive beings of society. As Malapit et al. (2019) mentioned, at the personal level of empowerment, an individual only becomes empowered when he/she utilizes the available resources. Initially, by recognizing their worth, women started to earn through handicrafts which boost their self-confidence and self-esteem. In this case, women are utilizing their resources (resources of time and material) to earn and this sense of earning from these resources is empowering them. The informants mentioned that the making of handicrafts gives them the power of decision-making.

\section{Conclusion}

The study aimed to present the experiences of women's empowerment with an in-depth understanding of the role of handicrafts in women's empowerment. The theoretical stance of Jo Rowlands on empowerment is related and viewed specifically with the experiences and situation of empowerment of women in Gilgit. This status further paved the way for the stabilized social status of women in society. As narrated by the craftswomen in Gilgit, they are empowering themselves with the skill of handicrafts.

This study strongly approved that women's economic and social position becomes stronger after starting to earn income. Women also felt like the source of change in terms of motivation, inspiration, and encouragement to the other women in the society. They viewed and regarded the skill of handicraft as the source of income and financial support for their families. The study recommends that further initiatives should be taken to uplift and strengthen women's empowerment through handicrafts and an institutional approach should be added to improve it.

\section{References}

Ali A, Bano N, \& Dziegielewski SF (2016) Role of AKRSP on gender development: A case study in Pakistan. Journal of Social Service Research 42 (4):548-555. https://doi.org/10.1080/01488376. 2015.1129019.

Ali TS, Asad N, Mogren I, \& Krantz G (2011) Intimate partner violence in urban Pakistan: Prevalence, frequency, and risk factors. International Journal of Women Health 3:105-115. https://dx.doi. org/10.2147\%2FIJWH.S17016. 
Bhandari T (2014) A study on women empowerment through income generation program in Dhurkot Rajasthal Vdc of Gulmi, District, Nepal. Thesis, Tribhuvan University, Kirtipur.

Bornstein D (2004) How to Change the World: Social Entrepreneurs and the Power of New Ideas. New York: Oxford University Press.

Brody C, Hoop T, Vojtkova M, Warnock R, Dunbar M, Murthy P, \& Dworkin SL (2016) Can self-help group programs improve women's empowerment? A systematic review. Journal of Development Effectiveness 9 (1):15-40. https://doi.org/10.1080/19439342.2016.1206607.

Bushra A \& Wajiha N (2015) Assessing the socio-economic determinants of women empowerment in Pakistan. Procedia - Social and Behavioral Sciences 177:3-8. https://doi.org/10.1016/j. sbspro.2015.02.321.

Dar MA \& Parrey AH (2013) Socio-economic potential of handicraft industry in Jammu and Kashmir: Opportunities and challenges. Journal of Research in Management \& Technology 2:20-28.

Datta PB \& Gailey R (2012) Empowering women through social entrepreneurship: Case study of a women's cooperative in India. Entrepreneurship Theory and Practice 36 (3):569-587. https://doi. org/10.1111/j.1540-6520.2012.00505.x.

Datta R (2003) From development to empowerment: The self-employed women's association in India. International Journal of Politics, Culture and Society 16 (3):351-368. https://doi. org/10.1023/a:1022352227601.

Datta U (2015) Socio-economic impacts of JEEViKA: A large-scale self-help group project in Bihar, India. World Development 68:1-18. https://doi.org/10.1016/j.worlddev.2014.11.013.

De Jong W (2013) Women's entrepreneurship in the EU. Library of the European Parliament. [Accessed 15 November 2021]. https://eige.europa.eu/docs/2041_LDM_BRI(2013)130517_REV1_EN.pdf.

Faiz-ur-Rehman, Ali RN, Aziz A, \& Iqbal A (2017) Potential of cottage industry in Azad Kashmir and the role of female entrepreneurship. Journal of Political Studies 24 (1):1-15.

Hashemi SM \& Schuler SR (1993) Defining and studying empowerment of women: A research note from Bangladesh. JSI Working Paper No. 3, Arlington, VA: JSI.

Hashemi SM, Schuler SR, \& Riley AP (1996) Rural credit programs and women's empowerment in Bangladesh. World Development 24 (4):635-653.

Hunt A\& Samman E (2016) Women's economic empowerment navigating enablers and constraints. ODI Development Progress. [Accessed 10 October 2021]. https://cdn.odi.org/media/documents/10683. pdf.

ILO (2012) Empower rural women - End poverty and hunger: The potential of African cooperatives. [Accessed 15 November 2021]. https://www.ilo.org/wcmsp5/groups/public/---africa/documents/ publication/wcms_174990.pdf.

Jabeen F, Friesen HL, \& Ghoudi K (2018) Quality of work life of Emirati women and its influence on job satisfaction and turnover intention. Journal of Organizational Change Management 31 (2):352-370. https://doi.org/10.1108/jocm-01-2017-0016.

Kabeer N (1999) Resources, agency, achievements: Reflections on the measurement of women's empowerment. Development and Change 30 (3):435-464.

Kabeer N (2011) Between affiliation and autonomy: Navigating pathways of women's empowerment and gender justice in rural Bangladesh. Development and Change 42 (2):499-528.

Kabir MS \& Huo X (2011) Advancement of rural poor women through small entrepreneurship development: The case of Bangladesh. International Journal of Business and Management 6 (9):134-140.

Khan H (2006) NGOs and gender development, the case of AKRSP1 in District Chitral, NWFP, Pakistan. The Lahore Journal of Economics 11 (1):81-98.

Kim JC, Watts CH, Hargreaves JR, Ndhlovu LX, Phetla G, Morison LA, Busza J, Porter JDH, \& Pronyk P (2007) Understanding the impact of a microfinance-based intervention on women's empowerment and the reduction of intimate partner violence in South Africa. American Journal of Public Health 97 (10):1794-1802. https://doi.org/10.2105/AJPH.2006.095521.

Liebl M \& Roy T (2003) Handmade in India: Preliminary analysis of crafts producers and crafts production. Economic and Political Weekly 38 (51/52):5366-5376. 
Makhdoom TR, Shah SA, \& Bhatti K (2016) Women's home-based handicraft industry and economic wellbeing: A case study of Badin Pakistan. The Women Annual Research Journal of Gender Studies 8 (8):41-52.

Malapit H, Quisumbing AR, Meinzen-Dick R, \& Seymour G (2019) Development of the project-level women's empowerment in agriculture index (pro-WEAI). World Development 122 (1):675-692. https://doi.org/10.1016/j.worlddev.2019.06.018.

Mohyuddin A, Chaudhry HR, \& Ambreen M (2012) Contribution of women in economic activities in rural Baluchistan: World system analysis at micro level in anthropological perspective. Academic Research International 3 (2):548-556.

Mosedale S (2005) Assessing women empowerment: Towards a conceptual framework. Journal of International Development: Wiley 17 (2):243-257. https://doi.org/10.1002/jid.1212.

Negi M, Rani A, \& Singh A (2016) New prospects for women empowerment through value addition of remnant fabrics with Aipan applique. Indian Research Journal of Extension Education 16 (3):8488.

Nicholls A (2006) Social Entrepreneurship: New Models of Sustainable Social Change. New York: Oxford University Press.

OECD (2016) Entrepreneurship at A Glance 2016. Paris: OECD Publishing Paris. http://dx.doi. org/10.1787/entrepreneur_aag-2016-en.

Paramanandam DA \& Packirisamy P (2015) An empirical study on the impact of micro enterprises on women empowerment. Journal of Enterprising Communities: People and Places in the Global Economy 9 (4):298-314. https://doi.org/10.1108/jec-08-2014-0017.

Paterson R (2008) Women's empowerment in challenging environments: A case study from Baluchistan: Development in Practice 18 (3):333-344. https://doi.org/10.1080/09614520802030383.

Rehman H, Moazzam A, \& Ansari N (2015) Role of microfinance institutions in women empowerment: A case study of Akhuwat, Pakistan. South Asian Studies 30 (1):107-125.

Richard N (2007) Handicrafts and Employment Generation for the Poorest Youth and Women. Paris: UNEVOC Library Catalogue. https://unesdoc.unesco.org/ark:/48223/pf0000156772.

Roomi MA\& ParrottG(2008)Barriers to development and progression of womenentrepreneurs in Pakistan. The Journal of Entrepreneurship 17 (1):59-72. https://doi.org/10.1177/097135570701700105.

Rowlands J (1995) Empowerment examined. Development in Practice 5 (2):101-107. https://doi.org/10 $.1080 / 0961452951000157074$.

Rowlands J (1997) Questioning Empowerment: Working with Women in Honduras. UK: Oxfam.

Saud M, Ashfaq A, \& Mas'udah S (2021) Women's attitudes towards wife beating and its connection with intimate partner violence (IPV): An empirical analysis of a national demographic and health survey conducted in Pakistan. Journal of International Women's Studies 22 (5):149-160.

Shealy S (2011) Her hands: Images of craftswomen in Uganda, Bolivia and India. Consilience 6 (1):291319.

Siddiq M \& Kakar B (2017) Hand embellished fabrics: An adoptable potential to empower household women in Balochistan. Bi-Annual Research Journal Balochistan Review 36 (1): 283-294.

Susanti E \& Mas'udah S (2017) Women's empowerment model in home-based industries in East Java Province, Indonesia. Masyarakat, Kebudayaan dan Politik 30 (4):353-366. http://dx.doi. org/10.20473/mkp.V30I42017.353-366.

Verheul I, Stel AV, \& Thurik R (2006) Explaining female and male entrepreneurship at the country level. Entrepreneurship \& Regional Development 18 (2):151-183. 